\title{
The Role of EU Funds in Improving Albania's PFM Reforms (2014-2020)
}

\author{
Jola Himçi Kepi \\ PhD Candidate, MBA, Director NAO Support Directorate, Ministry of Finance, Albania \\ Email: jola.himci@gmail.com; jola.himci@financa.gov.al
}

\section{Doi:10.5901/mjss.2017.v8n1p192}

\begin{abstract}
Strengthening Albanian public financial management is indeed a crucial basis for consolidating public finances and managing these in line with EU standards. Beyond the short term-measures on the existing EU support to PFM such as controls, audits and others, EU is seeking that Albania needs an overall, long-term public financial management policy in line with the EU standards. The purpose of this article is underlining the importance of EU funds in improving Albania in the way to reform its Public Finance Management for 2014-2020.
\end{abstract}

Keywords: EU funds, Country Albania, Public Finance Management, PFM reforms

\section{Introduction}

The Balkan countries have been significantly exposed towards the world crisis because as many of the Balkan countries have been highly indebted abroad, poses in-sufficient reserves related to their currencies and have faced high deficits in balance of payments In this fragile environment, Albania granted the Candidate status to the EU in 24 June 2014. The economic growth had been slow during 2012 with a growth shrink to 0.6, in 2013 about $1.3 \%$, in 2014 growth was projected at around 2.1\% (according to WB projections), in 2015 around 3\%, 2016 is projected to be $3.2 \%, 3.5 \%$ in 2017, and $3.8 \%$ in 2018.

The new Albanian Government in place since June 2013 committed its efforts in designing and implementing strong fiscal policies and structural reforms especially in the areas of public finance management (PFM). Recent development shows that the Government has reviewed its national development strategy and displaying commitment to address weaknesses in macro-economic and public finance management. This commitment is expressed in measured already agreed with IMF and WB and a clear intent has been expressed by the EU in order to support the Government for addressing the necessary public administration changes in terms of economic and public management governance, necessary for enabling PFM reforms. However, the EU financial aid through budget support to support the Albanian PFM reform will not be an easy exercise as the country has to meet four eligibility criteria: (1) Stable macro-economic framework, (2) sound public financial management, (3) transparency and oversight of the budget and (4) relevant and credible national/sector policy and reforms. For the reasons of weaknesses on current PFM and the absence of a credible PFM reform program which impact at the same time on the macro-fiscal situation, on the ability to assess progress towards improvement of the PFM system in spite of reform activities already implemented and on transparency and oversight of the budget, the Budget support as EU financial aid, will exclusively focus on the PFM reform programme so as to pave the way for future sector support. Through budget support to PFM reforms will help the Government of Albania improve: a) macroeconomic Stability, Improve Resource Mobilisation and allocation, b) Financial Discipline and Control, Strengthened Payroll and Pension Management, Improved Asset Management, Efficient and Transparent Financial Reporting and Procurement system, c) Institutional Strengthening of Oversight Function, Collaborative and Complimentary Approach to Oversight, Strengthened Follow up Mechanism of recommendations and, d) Enhanced Legal and Regulatory Framework, Enhanced IT infrastructure and controlled recurrent costs

\section{Albania in the EU Accession}

After collapse of the Communist regime (in 1991), Albania established the $1^{\text {st }}$ relations with EU, the diplomatic relations, followed then in 1992 by entering the Trade and Co-operation Agreement as eligible criteria for EU's funding under Phare programme. In the year 1997 under the Regional Approach the EC established the conditionality's for sustainable political and economic criteria to open the path for developing bilateral relations. In 1999 the European Union proposed 
the Stabilization and Association Process (SAP) for 5 South-Eastern European countries. Albania was one of the countries and the Stabilization and Association Agreement entered into force in 1st April 2009.

In 2003 Albania was recognized as a potential candidate country for accession into EU and it therefore submitted officially on $28^{\text {th }}$ of April 2009 the membership application. Albania granted the EU candidate status only recently on $24^{\text {th }}$ June 2014. The negotiations have not yet been open as the Government needs to address the key priorities related to public administration, reforms in judiciary system and fight against corruption, organized crime and fundamental rights. These cirterias are highlighted in the conclusions of Council of EC in December 2013.

\section{Albania and the EU Funds}

With the signature of Trade and Co-operation Agreement between the Government of Albania and EC in 1992, Albania became eligible for financial assistance under the EU's Phare programme and, from 2000, under the EU's CARDS financial assistance instrument. As from 1991 until 2001 Albania has benefited from EU funds around $912 \mathrm{mln}$ EUR in form of grant. From 2001 until 2006 it has benefited from the Stabilization and Association Process grants of $280 \mathrm{mln}$ EUR.

In year 2007 the European Union introduced a new financial instrument for candidate and potential candidate countries called financial Instrument for pre-accession (IPA) which covered financial assistance for a term of seven years (2007-2013)-called IPA I programming. This assistance is provided on the bases of achievements as state of progress made by Albania and the needs for financing required by Government as part of their good governance. The IPA financial assistance was designed to accommodate the needs of the beneficiary countries, in the context of alignment with the preaccession policy. The main objective of IPA financial assistance is to support governments by increasing institutionbuilding, improve and enforce rule of law, in improving policies in the field of human rights (incl. the fundamental freedoms), raise awareness in the minority rights, design policies for improving gender equality and non-discrimination. Further such financial assistance objective is to strengthen administrative and economic reforms, support the economic and social development, improve policies for reconciliation and reconstruction and support regional and cross-border cooperation as well as agriculture and rural development sector.

The table below represents the spread of EU financial assistance to Albania through years (source Ministry of European Integration).

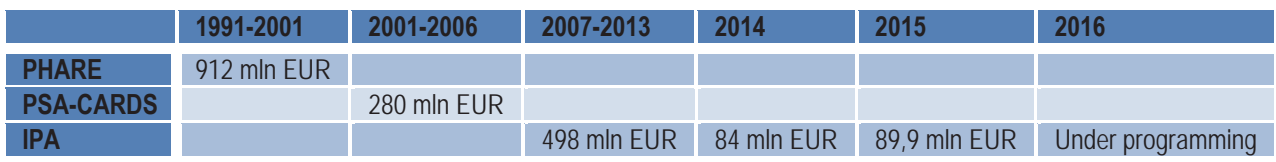

To insure effectiveness of the priorities designed in accordance to the needs of the governments benefiting for IPA I programming( 2007-2013), the programme is composed of five components; 1) Transitional Assistance and Institutional Building(TAIB), 2) Cross-Border Cooperation(CBC), 3) Human Resource Development (HRD), 4) Regional Development(RD) and 5) Rural Development or IPARD. The first two components concerns all beneficiary countries while the rest only to candidate countries. Therefore, until 2013 Albania could benefit only from the first two components, TAIB \& CBC. The amounts of EUR spread during this program are shown in the table below.

IPA I Programme (2007-2013)

\begin{tabular}{|lllllllll}
\hline & $\begin{array}{l}2007 \\
(\mathrm{mln} €)\end{array}$ & $\begin{array}{l}2008 \\
(\mathrm{mln} €)\end{array}$ & $\begin{array}{l}2009 \\
(\mathrm{mln} €)\end{array}$ & $\begin{array}{l}2010 \\
(\mathrm{mln} €)\end{array}$ & $\begin{array}{l}2011 \\
(\mathrm{mln} €\end{array}$ & $\begin{array}{l}2012 \\
(\mathrm{mln} €\end{array}$ & $\begin{array}{l}2007-2012 \\
(\mathrm{mln} €)\end{array}$ & $\begin{array}{l}2013 \\
(\mathrm{mln} €\end{array}$ \\
\hline Albania & 61.0 & 70.7 & 81.2 & 93.2 & 95.0 & 96.9 & 498.0 & 84.0 \\
\hline
\end{tabular}

The EU financial Assistance under IPA programme 2007-2013 to Albania has had an important role in improving the developments in areas of: strengthening the democratic institutions and improve the policies in the areas of rule of law; promoting and improving protection of the fundamental rights and freedom of expressions; reforms in public administration; reforms in justice and home affairs; modernization of the regulatory framework (incl. support by investing in equipment's for key institutions); establishment and improvements in the regulatory framework for enforcement of financial control systems; strengthening and opening new paths for a better market economy environment; strengthening the role of civil society in participating in process of decision making; establishment of a system for social dialogue as an 
element for good governance; promotion of minority rights and their integration into society, building confidence in all levels of society; improving policies in the area of environmental protection ; support for participation in community programmes; improvements in agriculture, infrastructure and cross border cooperation.

The new IPA approach will cover the period 2014-2020 and it differs from IPA I (2007-2013) because of its strategic approach. The new IPA programme will enable Albania by taking ownership of their own reforms and integrating them in development agendas. In this regard, the EU will support Albania in addressing and implementing its Public finance management reform (2014-2020); Reforms in Public Administration, Justice and Home affairs as the Government priority for development and reforms. Reforming the public finances is like reforming the state as it involves many institutions and stakeholders. Under IPA II (2014-2020) the EU is intended to give Budget Support (BS) to Albania in order to implement sector reform in the public finance management, public administration, employment and vocational training and is under programming for other sectors.

\section{Albanian Public Finance Management Reforms (2014-2020)}

Albania went smooth on the effects of financial and the global economic crises. The Government successfully avoided Recession, and the growth shock was less severe than elsewhere in Europe. However, growth has slowed down in the recent years, presenting an immediate development challenge. In this context, returning Albanian economy to the trajectory of fast-paced economic growth has been recognized as one the key government priorities. The Government has drafted a sound Public Finance Management reform strategy which will lie within 2014-2020. The strategy is finalized in autumn 2014 after consultation with all stakeholders (donor coordination) and other interested parties. To promote economic dynamism and to ensure healthy, democratic and harmonious society, PFM reforms will foster transparent interaction between the citizens and all levels of government. This interaction will be based on mutual trust and will be subject to adequate checks and balances.

The purpose of the Albanian PFM reform strategy is to; 1) Identify the weaknesses and address the challenges faced by public financial management in Albania and to evaluate the elements of the PFM reforms, required for continuous growth and development in the economy; 2) Promote coherence in policy making, to prioritize and take responsibilities in implementing the public financial management reforms; and 3) Increase transparency towards Parliament, the financial sector, reliable data for business community, increase sustainability for international partners and the public. Such polices are designed by the Government are to strengthen the public financial management in the country.

The public financial management strategy is built upon six main pillars; 1) Sustainable and prudent fiscal framework ; 2) Well-integrated and efficient planning and budgeting of public expenditure; 3) Efficient execution of the budget; 4) Modern Accounting and Reporting System; 5) Effective system of internal control at public units; 6) Effective oversight of the public finances. ${ }^{1}$

The expected reform outcomes are selected to improve Albania's public finance management and serve as clear direction for the institutions in developing their activities and reporting on their achievements.

Outcome 1:

1. Macroeconomic Stability

2. Improved Resource Mobilisation and allocation

Outcome 2:

1. Financial Discipline and Control

2. Strengthened Payroll and Pension Management

3. Improved Asset Management

4. Efficient and Transparent Financial Reporting and Procurement system

Outcome 3:

1. Strengthened Oversight Function Institutions

2. Collaborative and Complimentary Approach to Control and Oversight

3. Strengthened Follow up Mechanism of recommendations

Outcome 4:

1. Enhanced Legal and Regulatory Framework

2. Better IT Infrastructure and Rigorously Controlled Multi-year Budgetary Outlays

The strategy action plan includes the main components and actions to be undertaken in order to fulfil the strategic

1 Pillars as defined in Albanian PFM Strategy (2014-2020) 
objectives. It also contains the linkages to the outcomes. The intention is to improve all key aspects of public financial management and enhance transparency of budgetary analysis and control.

\section{The Role of EU Funds in Improving Albania's PFM Reforms}

On the way to accession process, and as reported in the EU directive on Budgeting, the Government of Albania complies with the EU principles for good governance in the management of public finances and fiscal policies. The Public Finance Management Reform of the Government of Albania was designed to comply with EU directives on Budgeting, this way when Albania will succeed towards the EU, these provisions will be met.

EU's Budget support as financial aid will exclusively focus on the PFM reform programme so as to pave the way for future sector support. The PFM reforms will be the basis of EU's first BS operation whilst the future NSDI will enable the EU to support the implementation of Albania's priority sector policies in a wider framework in the coming years. Stepping up EU budget support will provide a significant incentive for the government to address its PFM weaknesses while getting support to finance the gap in the public investment. Budget Support is also an incentive for addressing the necessary public administration changes in terms of economic and public management governance, necessary for enabling PFM reform. The EU's BS approach is an adequate tool to link fiscal management and macro-economic governance with public administration improvements through its four eligibility criteria.

In June 2014, EU has launched a policy dialogue with Albanian Government and key partner organizations in order to discuss relevance of PFM strategy and the financial support to be given to boost this sector. A preliminary $40 \mathrm{mIn}$ EUR through EU budget support has been in principle agreed to be given for PFM implementation and the first tranche of disbursement has successfully transferred to the Albanian Government after having fulfilled conditionality and its obligation under IPA 2014 programme. Such financial support will impact positively the public finance management in Albania and will improve : a) macroeconomic Stability, Improve Resource Mobilisation and allocation, b) Financial Discipline and Control, Strengthened Payroll and Pension Management, Improved Asset Management, Efficient and Transparent Financial Reporting and Procurement system, c) Institutional Strengthening of Oversight Function, Collaborative and Complimentary Approach to Oversight, Strengthened Follow up Mechanism of recommendations and , d) Enhanced Legal and Regulatory Framework, Enhanced IT infrastructure and controlled recurrent costs

\section{Conclusions}

Through EU' budget support to PFM reforms will help the Government of Albania improve: a) macroeconomic Stability, Improve Resource Mobilisation and allocation, b) Financial Discipline and Control, Strengthened Payroll and Pension Management, Improved Asset Management, Efficient and Transparent Financial Reporting and Procurement system, c) Institutional Strengthening of Oversight Function, Collaborative and Complimentary Approach to Oversight, Strengthened Follow up Mechanism of recommendations and, d) Enhanced Legal and Regulatory Framework, Enhanced IT infrastructure and controlled recurrent costs

\section{References}

Stabilization and Association Agreement between the Government of Albania and Council of European Union, 22 May 2006, Brussels, Belgium

Framework Agreement between the Government of Albania and European Communities, 28 October 2007.

IPA implementing regulation 718/2007

Draft strategy on Public Finance Management 2014-2020 of the Republic of Albania, June2014.

Towards a reform of Public Finance Management, Republic of Albania, Discussion Note by EC, February 2014.

Towards a Reform of Public Finance Management, Republic of Albania, 1st coaching note by EC, April 2014.

Frederic Tournemaine, 2007. "Can population promote income per-capita growth? A balanced perspective," Economics Bulletin, AccessEcon, vol. 15(8), pages 1-7. 